\title{
IAMJ
}

INTERNATIONAL

AYURVEDIC

MEDICAL JOURNAL

Research Article

ISSN: 2320-5091

Impact Factor: 6.719

\section{AN OBSERVATIONAL STUDY ON ASSESSMENT OF “INTELLIGENCE QUOTIENT” IN DIFFERENT PRAKRUTHI INDIVIDUALS}

\author{
Arjun. $\mathbf{N}^{1}$, Rajashekar K. $\mathbf{N}^{2}$ \\ ${ }^{1}$ Assistant Professor, Department of Kriya Shareera, Alvas Ayurveda Medical College, Moodbidri, Karnataka, \\ India \\ ${ }^{2}$ Professor, HOD Department of Kriya Shareera, Alvas Ayurveda Medical college, Moodbidri, Karnataka, India
}

Corresponding Author: arjunn.asok@gmail.com

https://doi.org/10.46607/iamj0109062021

(Published Online: June 2021)

Open Access

(C) International Ayurvedic Medical Journal, India 2021

Article Received: 04/05/2021 - Peer Reviewed: 02/06/2021 - Accepted for Publication: 04/06/2021

Check for updates

\begin{abstract}
Prakruthi is the innate constitution of an individual based on Dosha predominance determined at the time of conception which cannot be changed from birth till the death. Siblings of the same parents are not identical with each other in their physical strength, intellectual development, behaviour and reaction to various conditions of environment. Intelligence is a property of mind that is related to abilities, such as the capacity to reason, to plan, to solve problems, to think abstractly, to comprehend ideas, to use language, and to learn.
\end{abstract}

Keywords: Prakruthi, IQ

\section{INTRODUCTION}

According to Ayurveda definition of Swastha is an equilibrium state of Dosha, Agni, Dhathu, Mala and normal functioning of Athma, Mana, and Indriy ${ }^{l}$. Classifying human beings according to Prakruthi is one of the unique features of Ayurveda ${ }^{2}$. Ayurvedic classics have elaborately narrated the different Prakruthis and their importance. Basic concepts have given equal emphasis to both Physical and Psychological status of an individuals. The factors like Dhi, Drithi, Smrithi all together contribute the modern concept of Intelligence. Siblings of the same parents are not identical with each other in their physical strength, intellectual development, behaviour and reaction to various conditions of 
environment. There are various methods are in practice to evaluate Prakruthi of an individual. IQ is a score derived from one of the several different standardized tests to assess intelligence ${ }^{3}$. IQ is an important factor in success, dedication, motivation, confidence and social skills. IQ test is useful in psychological, sociological and educational research also.

Objective of the study

To assess the IQ in different Prakruthi.

To assess the possible relationship between Prakruthi and IQ.

\section{Materials and Methods}

\section{Source of data:}

150 Individuals from Alva's college and in and around Alva's campus with the age group of 20 to 22 years of age, under educational status, either sex was selected.

\section{Collection of data:}

Apparently healthy individuals were selected randomly.

Assesment of Prakruthi was done using standard proforma along with survey questionnaire. Individuals are made in to three groups A, B, C according to their Pradhana Prakruthi.

Group A- 50 volunteers who have Vata Pradhana Prakruthi were selected.

Group B -50 volunteers who have Pitta Pradhana Prakruthi were selected

Group C -50 volunteers who have Kapha Pradhana Prakruthi were selected.

\section{Inclusion criteria:}

Apparently healthy individuals, irrespective of sex, religion, having the age group of 20-22 years old.

\section{Exclusion criteria:}

Person with cognitive disorder

Acute and chronic systemic diseases

Mentally retarded

Psychological disorders.

\section{Assessment Criteria:}

Prakruthi of individual was assessed as per the self- assessment questionnaire designed by Dr. Kishor Patwardhan et.al ${ }^{4}$. IQ was assessed with the help of Wechsler Adult Intelligence scale 5 .

\section{Observation}

Distribution according to age

Table 1: Distribution according to age

\begin{tabular}{|l|l|l|}
\hline AGE & NO. OF INDIVIDUALS & $\%$ \\
\hline 20 & 48 & 32 \\
\hline 21 & 53 & 35.33 \\
\hline 22 & 49 & 32.66 \\
\hline TOTAL & 150 & 100 \\
\hline
\end{tabular}

Majority of subject were under the age group of 21 years $(35.33 \%)$ followed by 22 years $(32.66 \%)$ and $32 \%$ individuals were under 20 years of age group.

\section{Distribution according to sex}

Table 2: Distribution according to sex

\begin{tabular}{|l|l|l|}
\hline SEX & NO. OF INDIVIDUALS & $\%$ \\
\hline MALE & 69 & 46 \\
\hline FEMALE & 81 & 54 \\
\hline TOTAL & 150 & 100 \\
\hline
\end{tabular}

Out of 150 subjects maximum numbers were female's i.e. $54 \%$, followed by males $46 \%$. 


\section{Distribution according to religion}

Table 3: Distribution according to religion

\begin{tabular}{|l|l|l|}
\hline RELIGION & NO. OF INDIVDUALS & $\%$ \\
\hline HINDU & 109 & 72.66 \\
\hline CHRISTIAN & 17 & 11.33 \\
\hline MUSLIM & 24 & 16 \\
\hline TOTAL & 150 & 100 \\
\hline
\end{tabular}

Maximum subjects were Hindu religion i.e. $72.66 \%$, followed by Muslims $16 \%$ and other religion like Christians constitute $11.33 \%$.

Distribution according to socio economic status

Table 4: Distribution according to socio economic status

\begin{tabular}{|l|l|l|}
\hline S-E-S & NO. OF INDIVIDUALS & $\%$ \\
\hline MCL & 118 & 78.66 \\
\hline HCL & 32 & 21.33 \\
\hline TOTAL & 150 & 100 \\
\hline
\end{tabular}

Distribution according to diet

Table 5: Distribution according to diet

\begin{tabular}{|l|l|l|}
\hline DIET & NO. OF INDIVIDUALS & $\%$ \\
\hline VEG & 52 & 34.66 \\
\hline MIXED & 98 & 65.33 \\
\hline TOTAL & 150 & 100 \\
\hline
\end{tabular}

Distribution According to Exercise

Table 6: Distribution according to exercise

\begin{tabular}{|l|l|l|}
\hline EXERCISE & NO. OF INDIVIDUALS & $\%$ \\
\hline YES & 63 & 42 \\
\hline NO & 87 & 58 \\
\hline TOTAL & 150 & 100 \\
\hline
\end{tabular}

Distribution According to Siblings

Table 7: Distribution according to siblings

\begin{tabular}{|l|l|l|}
\hline ORD.OF SIBLINGS & NO. OF INDIVIDUALS & $\%$ \\
\hline FIRST & 72 & 48 \\
\hline SECOND & 52 & 34.66 \\
\hline THIRD & 23 & 15.33 \\
\hline TOTAL & 150 & 100 \\
\hline
\end{tabular}

\section{Distribution according to sleep}

Table 8: Distribution according to sleep

\begin{tabular}{|l|l|l|}
\hline SLEEP & NO. OF INDIVIDUALS & $\%$ \\
\hline SOUND & 130 & $86 \%$ \\
\hline DISTURBED & 20 & $13.33 \%$ \\
\hline TOTAL & 150 & \\
\hline
\end{tabular}




\section{Distribution according to habit}

Table 9: Distribution according to habit

\begin{tabular}{|l|l|l|}
\hline HABIT & NO.OF INDIVIDUALS & $\%$ \\
\hline YES & 26 & 17.33 \\
\hline NO & 124 & 82.66 \\
\hline TOTAL & 150 & 100 \\
\hline
\end{tabular}

Distribution according to prakruthi

Table 10: Distribution according to prakruthi

\begin{tabular}{|l|l|l|}
\hline PRAKRUTHI & NO. OF INDIVIDUALS & $\%$ \\
\hline VATA & 50 & 33.33 \\
\hline PITTA & 50 & 33.33 \\
\hline KAPHA & 50 & 33.33 \\
\hline TOTAL & 150 & 100 \\
\hline
\end{tabular}

\section{Distribution According To IQ}

Distribution According to Prakruthi In Relation To Various Parameters

Table 11: Distribution according to IQ

\begin{tabular}{|l|l|l|}
\hline IQ & NO. OF INDIVIDUALS & $\%$ \\
\hline $80-100$ & 21 & 14 \\
\hline $101-110$ & 59 & 39.33 \\
\hline $111-120$ & 50 & 33.33 \\
\hline $121-130$ & 20 & 13.33 \\
\hline TOTAL & 150 & 100 \\
\hline
\end{tabular}

Distribution of prakruthi in relation to sex

Table 12: Distribution of prakruthi in relation to sex

\begin{tabular}{|l|l|l|l|l|l|l|}
\hline SEX & VATA & $\%$ & PITTA & $\%$ & KAPHA & $\%$ \\
\hline MALE & 15 & 10 & 28 & 18.66 & 26 & 17.33 \\
\hline FEMALE & 35 & 23.33 & 22 & 14.66 & 24 & 16 \\
\hline TOTAL & 50 & & 50 & & 50 & \\
\hline
\end{tabular}

In overall stud, male subjects having vata prakruthi are found $10 \%$, pitta $18.66 \%$, kapha $17.33 \%$ while female subjects with vata prakruthi $23.33 \%$, pitta $14,66 \%$, kapha $16 \%$.

Distribution of prakruthi in relation to diet

Table 13: Distribution of prakruthi in relation to diet

\begin{tabular}{|l|l|l|l|l|l|l|}
\hline DIET & VATA & $\%$ & PITTA & $\%$ & KAPHA & $\%$ \\
\hline VEG & 5 & 3.33 & 19 & 12.66 & 28 & 18.66 \\
\hline MIXED & 45 & 30 & 31 & 20.66 & 22 & 14.66 \\
\hline TOTAL & 50 & & 50 & & 50 & \\
\hline
\end{tabular}

In overall study, the subjects taking vegetarian diet are found having vata prakruthi $3.33 \%$, pitta $12.66 \%$, kapha $18.66 \%$ while subjects taking mixed diet are found vata prakruthi $30 \%$, pitta $20.66 \%$, kapha $14.66 \%$ 
Distribution of prakruthi in relation to order of siblings

Table 14: Distribution of prakruthi in relation to siblings

\begin{tabular}{|l|l|l|l|l|l|l|}
\hline ORD.OF SIBLINGS & VATA & $\%$ & PITTA & $\%$ & KAPHA & $\%$ \\
\hline FIRST & 23 & 15.33 & 26 & 17.33 & 23 & 15.33 \\
\hline SECOND & 21 & 14 & 17 & 11.33 & 17 & 11.33 \\
\hline THIRD & 6 & 4 & 7 & 4.66 & 10 & 6.66 \\
\hline TOTAL & 50 & & 50 & & 50 & \\
\hline
\end{tabular}

In overall study, the subjects of first order sibling have vata prakruthi $23 \%$, pitta $17.33 \%$, kapha $15.33 \%$, while second order sibling have vata prakruthi $14 \%$, pitta $11.33 \%$, kapha $11.33 \%$, and third order sibling have vata prakruthi $4 \%$, pitta $4.66 \%$, kapha $6.66 \%$.

Distribution of prakruthi in relation to sleep

Table 15: Distribution of prakruthi in relation to sleep

\begin{tabular}{|l|l|l|l|l|l|l|}
\hline SLEEP & VATA & $\%$ & PITTA & $\%$ & KAPHA & $\%$ \\
\hline SOUND & 38 & $25.33 \%$ & 44 & $29 \%$ & 48 & $32 \%$ \\
\hline DISTURBED & 12 & $8 \%$ & 6 & $4 \%$ & 2 & $1.33 \%$ \\
\hline TOTAL & 50 & & 50 & & 50 & \\
\hline
\end{tabular}

In overall study, the subjects were getting sound sleep are found having vata prakruthi $25.33 \%$, pitta $29 \%$, kapha $32 \%$, while subjects having disturbed sleep are found vata prakruthi $8 \%$, pitta $4 \%$, kapha $1.33 \%$.

Distribution of prakruthi in relation to exercise

Table 16: Distribution of prakruthi in relation to exercise

\begin{tabular}{|l|l|l|l|l|l|l|}
\hline EXERCISE & VATA & $\%$ & PITTA & $\%$ & KAPHA & $\%$ \\
\hline YES & 21 & 14 & 22 & 14.66 & 20 & 13.33 \\
\hline NO & 29 & 19.33 & 28 & 18.66 & 30 & 20 \\
\hline TOTAL & 50 & & 50 & & 50 & \\
\hline
\end{tabular}

In overall study, the subject has doing exercise are found vata prakruthi $14 \%$, pitta $14.66 \%$, kapha a $13.33 \%$, while subject were not doing exercise are found vata prakruthi $19.33 \%$, pitta $18.66 \%$, kapha $20 \%$.

\section{Distribution of prakruthi in relation to habit}

Table 17: Distribution of prakruthi in relation to habit

\begin{tabular}{|l|l|l|l|l|l|l|}
\hline HABIT & VATA & $\%$ & PITTA & $\%$ & KAPHA & $\%$ \\
\hline YES & 4 & 2.66 & 15 & 10 & 7 & 4.66 \\
\hline NO & 46 & 30.66 & 35 & 23.33 & 43 & 28.66 \\
\hline TOTAL & 50 & & 50 & & 50 & \\
\hline
\end{tabular}

In overall study, the subject with habit have vatha prakruthi $2.66 \%$, pitta $10 \%$, kapha $4.66 \%$ while without habit found vata prakruthi $30.66 \%$, pitta prakruthi $23.33 \%$, kapha prakruthi $28.66 \%$. 


\section{Distribution of prakruthi inrelation to bmi}

Table 18: Distribution of prakruthi in relation to BMI

\begin{tabular}{|l|l|l|l|l|l|l|}
\hline BMI & VATA & $\%$ & PITTA & $\%$ & KAPHA & $\%$ \\
\hline $\begin{array}{l}\text { LESS THAN } \\
18.5\end{array}$ & 22 & 14.66 & 5 & 3.33 & 2 & 1.33 \\
\hline $18.5-24.9$ & 25 & 16.66 & 35 & 23.33 & 23 & 15.33 \\
\hline $25-29.9$ & 3 & 2 & 9 & 6 & 24 & 16 \\
\hline ABOVE 30 & 0 & 0 & 1 & 0.66 & 1 & 0.66 \\
\hline TOTAL & 50 & & 50 & & 50 & \\
\hline
\end{tabular}

Among vata prakruthi subjects having BMI (18.5-24.9) $16.66 \%$, pitta $23.33 \%$, kapha $15.33 \%$, BMI (>18.5) vata $14.66 \%$, pitta $3.33 \%$, kapha $1.33 \%$. BMI (25-29.9) vata $2 \%$, pitta $0.66 \%$, kapha $0.66 \%$, BMI $(<30)$ vata $0 \%$, pitta $0.66 \%$, kapha $0.66 \%$.

\section{Statistical analysis}

Data were collected in an excel sheet and analyzed by using Sigma stat software.

\section{RESULTS}

\section{(a) Comparison of IQ score in Prakruthi (Assessment by One-way analysis of Variance)}

Table 19: Comparison of IQ score in Prakruthi

\begin{tabular}{|l|l|l|l|l|}
\hline PRAKRUTHI & freq(N) & MEAN IQ & S.D & S.E \\
\hline VATA & 50 & 103.78 & 10.51 & 1.48 \\
\hline PITTA & 50 & 113.64 & 9.01 & 1.27 \\
\hline KAPHA & 50 & 110.18 & 6.92 & 0.97 \\
\hline $\mathrm{F}=15.657 \quad$ d.f. $=2$ & $\mathrm{P}=<0.001$ & & \\
\hline
\end{tabular}

Vata prakruthi subjects were found to have lowest mean IQ-103.78, pitta prakruthi subjects were found to have highest mean IQ-113.64, whereas kapha prakruthi subjects were found to have mean IQ-110.18. The difference in between the groups is statistically significant $(\mathrm{F}=15.657, \mathrm{P}=<0.001)$.

\section{IQ relation with prakruthi}

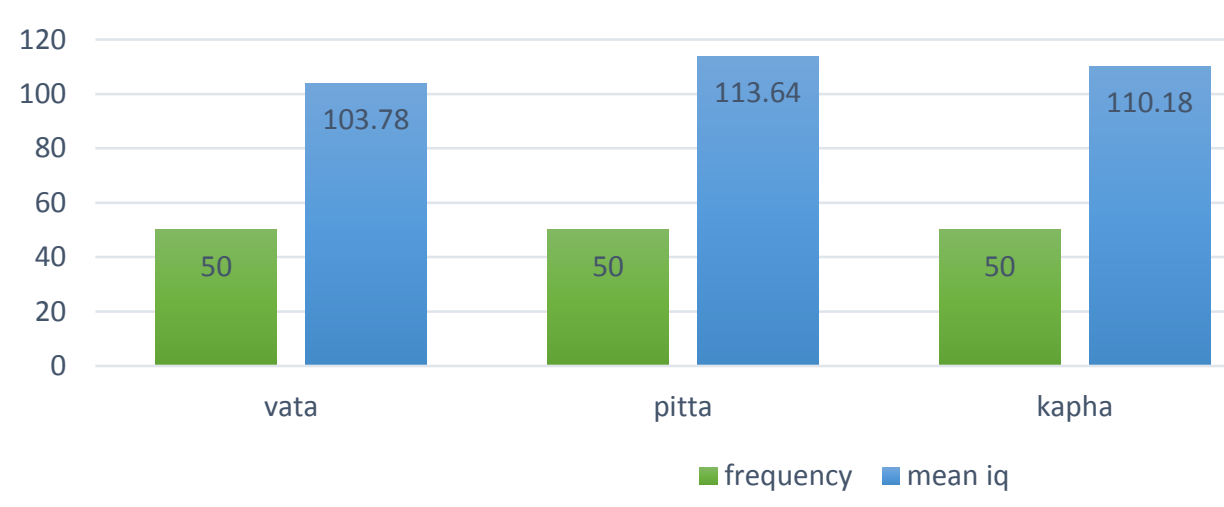


(b) Comparison of IQ scores In order of siblings. (Assessment by Kruskal Wallis One-way Analysis)

Table 20: Comparison of IQ score in order of siblings

\begin{tabular}{|l|l|l|l|l|}
\hline ORD.OF SIBLINGS & Freq(N) & MEAN IQ & S.D & S.E \\
\hline FIRST & 72 & 111 & 9.94 & 1.17 \\
\hline SECOND & 55 & 106.69 & 10.31 & 1.39 \\
\hline THIRD & 23 & 109.56 & 6.41 & 1.33 \\
\hline F=3.133 d.f=2 p=<0.001 & & & \\
\hline
\end{tabular}

Mean IQ for first order sibling is 111, while that of second order sibling is 106.65 and third order sibling is 109.56. The difference in between the groups is statistically significant $(\mathrm{F}=3.133, \mathrm{P}=<0.001)$

\section{(i) Comparison of IQ scores in Sleep (Assessment by Mann-Whitney Rank Sum Test)}

Table 21: Comparison of IQ score in sleep

\begin{tabular}{|l|l|l|l|l|l|}
\hline SLEEP & Freq(N) & MEAN IQ & MEDIAN IQ & $25 \%$ & $75 \%$ \\
\hline DISTURBED & 20 & 95.2 & 94 & 89.5 & 102 \\
\hline SOUND & 230 & 111.35 & 112 & 106 & 116 \\
\hline $\mathrm{T}=390.500 \quad \mathrm{P}=<0.001$ & & & & & \\
\hline
\end{tabular}

The mean IQ for having sound sleep subject was 111.35, while those having disturbed sleep were 95.2. There is difference in between the groups is statistically significant. $(\mathrm{P}=<0.001)$

(g) Comparison of IQ scores in exercise (Assessment by Mann-Whitney Rank Sum Test)

Table 22: Comparison of IQ score in exercise

\begin{tabular}{|l|l|l|l|l|l|}
\hline EXERCISE & Freq(N) & MEAN IQ & MEDIAN IQ & $25 \%$ & $75 \%$ \\
\hline YES & 63 & 111.159 & 108 & 104 & 121 \\
\hline NO & 87 & 107.784 & 108 & 103 & 115.75 \\
\hline $\mathrm{T}=5153 \quad \mathrm{P}=0.131$ & & & & & \\
\hline
\end{tabular}

The subjects with doing exercise were having mean IQ of 111.159, while with higher class status were having mean IQ of 109. The difference in mean between 2 groups is not great enough exclude the possibility that difference is due to random variability. There is not statistically significant difference $(\mathrm{p}=0.131)$

\section{DISCUSSION}

The concept of Prakruthi is unique one and unanimously accepted by all the Acharyas of our science. Considering the improbable significance of it in theoretical as well as clinical aspects it should be well understood, as it furnishes the base for existence of health or disease of a person. The most comprehensive definition of prakruthi is that favourable state of Dosha formed at the formation of Garbha due to self-excitatory cause and which runs from birth to death. In other words, prakruthi is group of characters inherited prior to birth right at the time of conjunction of Shukra and Shonita, but non-afflictory to the individual himself just as a poisonous creature survives even born out of poison. Although the single cell structure undergoes division to form innumerable cells in the body, still leaves some dissimilarities in contour of the body, immunity, susceptibility, knowledge, intelligence etc. quantitatively as well as qualitative, The cause and effect of all these events are dealt in detail under genetics in modern whereas we have to learn forward to the concept of Prakruthi to explain the same. Overall, the constitution is the sum of the physique, physiological and psychological attributes of an individual. Though the contributions of them may vary, the unassailable influence of psychological attributes over the rest is enormous. 


\section{Discussion on prakruthi and IQ}

Equal number of subjects in 3 groups, Vata Pradhana subject were present more IQ groups 101-110 as well as $80-100$, Kapha pradhana Prakruthi subjects were clustered in IQ groups 111-120, comparatively more Pitta Pradhana Prakruthi subject were there in IQ groups 121-130. Deha Prakruthi when under observation has shown which influence on the mental factors. Hence that can be possibility of a definitive relation between IQ and Prakruthi. In this study results reveal that the IQ considering Dhee, Dhriti, Smriti, Buddhi etc. In Ayurveda, the concept of intelligence can be found spread under different heading - Buddhi, Jnana, Prajna, Medha, Dhee, Dhriti and Smriti etc. From this we can infer intelligence cannot be included under single terminology. But broadly we can say Dhee, Dhriti, Smriti are the three dimensions of Buddhi.

After thorough observation the results revealing that people having Pitta pradhana Prakruthi seems to have higher IQ. Hence here by stating the words of Acharya that people with of pitta prakruthi are said to be Medhavi, ${ }^{6}$ Nipunamathi, ${ }^{7}$ Vaibhava, Pandita, and Sahasa Budddhi, ${ }^{8}$ are the same Lakshanas which are seen in people with higher IQ in Pitta Prakruthi. By this stating that people with Pitta Pradhana Prakruthi are said to possess higher IQ than others.

\section{Discussion on siblings}

Mean IQ for first order sibling is 111, while that of second order sibling was 106.65. In 1874 Francis Galton offered several reasons; Primogeniture law ${ }^{9}$ : first born sons would be more likely have the financial resources to continue their education. They also have the advantage of being "this means that they also undertake more responsibility than their younger siblings. The eldest siblings would get more attention and better nourishment in families with available financial resources. The resource dilution model: ${ }^{10,11}$ this resource dilution model, proposed by Blake (1981) and elaborated by Downey (2001). Parental resources are finite, resource include money, personal attention and cultural object such as books. Additional siblings reduce the share of parental resources received by any one child.
Parental resources have an important effect on children's educational success. The difference in between the groups is statistically significant.

\section{Discussion on sleep}

Nidra according to Acharya is said to be effectively help in the formation of Jnana. ${ }^{12}$ which is also a factor responsible for identifying IQ of a person. From the observation the results derived shows that volunteers who were having sound sleep had greater IQ value than people with disturbed sleep pattern. Here mean values of sound sleep-111.35 and disturbed sleep-95.2. This result is suggestive of opinion that proper sleep is a major contributing factor in formation of IQ. ${ }^{13}$

\section{Discussion on exercise}

In this study conducted $42 \%$ of subject were habituated to physical exercise those are the ones who have had higher IQ than the rest. It is said that when we exercise 'growth factor' are released, which influence the brain health and in turn effects the hippocampus, which govern the learning and memory. ${ }^{14}$

\section{CONCLUSION}

Prakruthi of a person cannot be changed from birth to death. The formations of Prakruthi are influenced by many factors even before the formation of Garbha. In Ayurveda the exact terminology for intelligence cannot be found, rather terms relating with the concept of intellect like Dhi, Dhriti, Smriti, Buddhi, Medha etc. For the development of IQ there are certain influential factors are there, like sleep, standard of living, resources etc. The results showed Pitta Pradhana Prakruthi to have more IQ than the rest of combinations of Prakruthi. Hence from this study a significant relation was seen, between Prakruthi and IQ. Hence stating H1 to be accepted.

\section{REFERENCE}

1. Sushrutha. Sushrutha Samhitha Dalhana. In: Acharya YT edi. Nibandhasangraha Commentary. Reprint ed. Varanasi: Chaukhambha Sanskrit Sansthan; 2012. Sutra sthana, ch-15, sloka no 41, pp. 75

2. Agnivesha. Charaka Samhitha. Chakrapanidatta. In: Acharya YT edi. Ayurveda Dipika Commentary. Reprint ed. Varanasi: Chaukhambha Prakashan; 2011. Vimanasthana ch-8, sloka no-95 pp. 277 
3. Stern 1914, pp. 48-58 (1912 original German edition by stern); 70-84 (1914 English translation by Whipple)

4. K. Patwardhan and R. Sharma, "Prakriti: a self-assessment questionnaire," Journal of All India Sharir Research Institute, vol. 1, no. 5, pp. 11-16, 2005.

5. "Wechsler Adult Intelligence Scale-Revised, Fourth Edition Now Available From Pearson" (Pressrelease).Pearson.2008-08-28.Retrived 2012-03-20.

6. Sushrutha. Sushrutha Samhitha Dalhana. In: Acharya YT edi. Nibandhasangraha Commentary. Reprint ed. Varanasi: Chaukhambha Sanskrit Sansthan; 2012. Shareerasthana; ch- 4, sloka no 8, pp. 355

7. Sushrutha. Sushrutha Samhitha Dalhana. In: Acharya YT edi. Nibandhasangraha Commentary. Reprint ed. Varanasi: Chaukhambha Sanskrit Sansthan; 2012. Shareerasthana; ch- 4, sloka no 68, pp. 361

8. Vagbhata. Astangahrdaya. Arunadatta. In: Hari Sadasiva Sastri edi. Sarvangasundara Commentary. Reprint ed. Chaukhambha Sanskrit Sansthan; 2011. Shareerasthana; ch-3, sloka no 90, pp. 403

9. Galton, F. (1874, 1895). English of science, their nature and nurture, New York: D, Appleton and company

10. Blake, J. (1981) Family size and the quality of children, Demography, 18, 421-442.

11. Downey, D.B (2001), Number of siblings and intellectual development: the resource dilution explanation, American psychologist, 56(6(7), 497-504

12. Agnivesha. Charaka Samhitha. Chakrapanidatta. In: Acharya YT edi. Ayurveda Dipika Commentary. Reprint ed. Varanasi: Chaukhambha Prakashan; 2011. Sutrasthana; ch- 21, sloka no 36, pp. 118

13. Earth, S.A., Tu, K. M., Buckhalt, J. A., \& EI-Sheikh, M. (2015). Association between children's intelligence and academic achievement: the role of sleep. Journal of sleep research, 24(5), 510-513

14. American physiological society. "Exercise increases Brain Growth Factor Receptors Prevent Stem Cell Drop In Middle Age." science daily. Sciencedaily, 27 November 2008 .

\section{Source of Support: Nil Conflict of Interest: None Declared}

How to cite this URL: Arjun. N \& Rajashekar K. N: An Observational Study On Assessment Of "Intelligence Quotient" In Dif-Ferent Prakruthi Individuals. International Ayurvedic Medical Journal \{online\} 2021 \{cited June, 2021 \} Available from: http://www.iamj.in/posts/images/upload/1158 1166. 